\title{
Inter-Industrial Trade on Iran's Air Pollution
}

\author{
Maryam Asghari, Mohamad Hosein Mohamadi* \\ Shahid Ashrafi Esfahani University, Esfahan, Iran \\ Email: Maryam.Asghari@Ashrafi.ac.ir, “mh.mohamadi1986@yahoo.com
}

Received 18 February 2016; accepted 30 April 2016; published 3 May 2016

Copyright (C) 2016 by authors and Scientific Research Publishing Inc.

This work is licensed under the Creative Commons Attribution International License (CC BY). http://creativecommons.org/licenses/by/4.0/

c) (7) Open Access

\begin{abstract}
The related issues to trade liberalization and its impact on the environmental quality have become important since late 1996. The previous studies have shown that there has not been consensus among the economists in this field. Paper is analyzing the effect of inter-industrial trade on the Iran's air pollution. Also in this paper, the pollution haven hypothesis is tested in Iran. To study the effect of inter-industrial trade on the environment in two ways: 1) direct effect on the environment and 2) an indirect effect through growth and the effect of growth on the environment were examined. The model has been estimated by using the panel data method for Iran's various industrial sectors over 1980-2014. The results show that inter-industrial trade has positive effect on Iran's air pollution. Also, pollution haven hypothesis is valid in Iran.
\end{abstract}

\section{Keywords}

Trade Liberalization, Environmental Quality, Pollution Haven Hypothesis, Industry

\section{Introduction}

Today developed world is in favor of opening economies as well as for more trade openness, as trade openness has beneficial impact on economic growth. This rising level of trade openness has started the debate that changing trade pattern may bring environmental changes in the globe of world. Grossman and Krueger [1], start the debate that trade openness has significant impact on environmental quality. The proponents of trade openness treat quality of environment as a normal good as the level of traded income rises, people attached with this income demand clean environment. The authorities discourage the old and outdated techniques of production. The proponents of trade openness suppose that trade openness creates win-win situation which improves the economy and environment as a whole. But on other hand, opponents of trade openness claim that trade openness sti-

"Corresponding author. 
mulates economic activity and that quality of environment is deteriorated if the techniques of production are unchanged.

They suppose that if quality of environment is a normal good then firms in developing countries move towards lower standard of production due to relax rules and regulations of environment. This process may raise distribution of income at world level; trade openness favors growth of pollution-intensive industries in case of developing countries as developed countries enforce strict environmental regulations, thereby having a significant adverse effect on environmental quality [2] [3].

Grossman and Krueger [4] emphasize the role of international trade on the environment and decompose the effects of trade openness into three separate mechanisms as follows: scale, technique, and composition effects. The scale effect refers to an increase in pollution emissions resulting from economic expansion by trade openness. The technique effect refers to a reduction in pollution emissions due to the demand for stricter environmental regulations with rising income. The composition effect refers to a change in the industrial structure through trade openness. In particular, the pollution haven hypothesis ( $\mathrm{PHH}$ ), which asserts that dirtier industries move from developed countries to developing countries, remains controversial.

Since the conjunction of differences in environmental policies and in the determinants of trade across countries may lead to the migration of "dirty" industries to countries with emission-intensive production techniques, the rapid growth of world trade has given fuel to the alarmists who claim that trade is bad for the environment, and to a large and still unsettled debate about the pollution haven hypothesis. Suspicions about the validity of the PHH have recently been echoed in doubts about the existence of an EKC.

The aim of this study is to examine the effect of trade openness on Iran's $\mathrm{CO}_{2}$ emissions. As an individual country, level of income as well as the composition of traded commodities, level of emissions intensity, can give better understanding about the effect of trade openness on $\mathrm{CO}_{2}$ emissions [5].

This study is a healthy contribution towards respective literature by four folds: 1) it is studying the indirect relationship between trade openness and $\mathrm{CO}_{2}$ emissions through economic growth; 2) it is pioneering effort investigating the direct relationship between trade openness and $\mathrm{CO}_{2}$ emissions by adding scale, technique, composite and comparative advantage effects in $\mathrm{CO}_{2}$ emissions function; 3) the bounds testing approach is applied for checking the presence of pollution haven hypothesis.

\section{Indirect Relation between Trade Liberalization and Environment}

\subsection{Effect of Trade Liberalization on Economic Growth}

As seen in many countries, the principal motive of governments especially in recent years has been to obtain high and sustainable economic growth so as to prevail in a challenging world of trade relations [6]. According [6], trade liberalization policies open up the opportunity for countries' economies to enhance growth and foster overall development. In attaining this principled goal, countries have embarked themselves in popular economic policies that allow reduction and removal of barriers to trade such as tariffs, quotas and import controls as to mention but three. Among many policies that most countries have decided to opt-for is trade liberalization of economies [7].

Theories regarding trade relations to economic growth of countries mostly owe their basis from the Ricardian Comparative Advantage theory and Hecksher-Ohlin Factor Endowment theory. In his book of 1817, David Ricardo advocated that two countries will conduct a mutual beneficial trade if they specialize and trade commodities which they produce at lowest opportunity cost. With free trade and elimination of trade, global trade will be promoted with effective utilization of resources given the state of technology. However, this theory of comparative advantage has encounter empirical problems.

On the other hand, Heckscher-Ohlin (H-O) theory advocated that trade between countries depends on relative factor abundance. There will be a great mutual beneficial trade if the trading countries have larger differences in technology and factor endowments. Little trade is expected between the countries with similar factor endowments. This theory describes what we call a pattern of "North-South" trade pattern. However, the empirical findings from USA by Wassily Leontief deviated from the theory and criticized H-O theory and gave rise to a problem of Leontief Paradox. This is occurs when a capital abundant country is exporting more in labor intensive commodities and vice versa.

The criticism against international trade theory arises from the validity of some of the assumptions made by the proponents of the theory. For example, it is not obvious that all productive resources have identical quality 
or are perfectly mobile within and across the trading countries. Neither is the technology of production similar nor the markets are always competitive seeking cost minimization and profit maximization. Under these circumstances the realized benefits from trade may diverge from the intended benefits.

Moreover, even if trade is found to stimulate growth it is not obvious if growth can automatically translate into poverty reduction. Growth is necessary but not sufficient condition for poverty reduction. It should also be recognized that Poverty and Income inequalities are in themselves two different concepts and outcomes. Anti-globalization and anti-growth thinking that dominates among non-economists today stems largely from the considerations of income inequalities and disparities. The distributional effects of trade have not been necessarily positive or benign.

\subsection{Effect of Economic Growth on Environment}

In 1991, Grossman and Krueger [1] as earlier works found that the long-term relationship between economic growth and environment quality was an inverted U-shaped curve. The phenomenon has been labeled as Environmental Kuznets Curve (EKC) by Panayotou [8] later. The EKC hypothesizes that environment quality deteriorates with the increase of per capita income at the early stage of economic growth and gradually improves when the country reaches to a certain level of affluence. Since then, extensive empirical studies have been conducted to test the EKC hypothesis and the effect of economic growth on environmental quality is much under dispute ${ }^{1}$.

\section{Direct Effect of Trade Liberalization on Environment}

Theoretical relationship between trade openness and environmental quality is not clear but developed countries have recently raised concerns over the dirty industries of developing countries as it changes the structure of comparative advantages. Firms in developed countries have to face strict domestic environmental regulations compared to developing countries. But on other hand, developing countries are concerned that trade liberalization will promote specialization in dirty industries, thus aggravating environmental damage [9]. The modern world is now divided into trade blocks and trade openness has the potential to affect not only socio-economic well-being of the nations in trade block, but also environmental quality enjoyed by all states involved in the agreements; that such a trade-environment relationship exists is well-established and widely accepted [10] [11]. Such type of relationship is visible in trade liberalization agreements among countries with a marked developmental imbalance [12].

Grossman and Krueger [1] emphasize the role of international trade on the environment and decompose the effects of trade openness into three separate mechanisms as follows: scale, technique, and composition effects.

The Scale, Technique and Composition effect theory was originally developed to better understand how trade liberalization between developed and developing countries affected Industrial air-pollution levels.

Scale effect

Empirical evidence has long linked trade liberalization to economic and output growth, as it opens access to previously restricted markets, while encouraging Foreign Direct Investment (FDI) in productive assets. Increased Scale of production may place greater stress on the environment as, assuming constant Composition and Technique effects, more inputs and resources are required to satisfy the increased demand. Given this, the Scale effect generally indicates an increase in environmental degradation. In the agricultural sector, this can be translated into, for example, environmental stresses related to increased use of inputs such as water and agrochemicals or the expansion of the agricultural frontier to marginal land.

\section{Composition effect}

Trade liberalization may affect the Composition of national output by encouraging some economic sectors and limiting others and hence altering the incidence, type and level of pollution (or environmental degradation) across regions and countries. Thus, the Composition effect measures the change in environmental degradation due to changes in the range of goods produced, assuming constant Scale and Technique of production. Environmental effects can be positive or negative depending on the pattern of trade-induced specialization. In the case of agriculture, given that different crops require different levels and types of agricultural inputs, specializ-

\footnotetext{
${ }^{1}$ Some papers supported the existence of EKC, while some other papers did not support EKC hypothesis in addition the studies using panel data usually accepted inverted U-shaped hypothesis, while the studies using particular national time series data, generally, rejected this hypothesis [12].
} 
ing on let's say, grains versus horticulture, will have on itself an effect on the use of environmental resources.

Technique effect

Economic theory predicts that output growth promoted by trade liberalization increases incomes, and wealthier countries tend to be more willing and able to channel resources into environmental protection through the establishment of higher environmental standards and the investment on more sustainable technologies. The Technique effect is then determined by the combined influence of incomes and a producers' response to market and institutional incentives The Technique effect thus measures the change in aggregate pollution (or environmental degradation) arising from a switch to more environmentally sustainable production Techniques, assuming constant Scale and Composition effects. In the case of agriculture, trade liberalization may affect the producers' choice of adopting expansive versus input-intensive agricultural methods, as well as the uptake of more sustainable agricultural technologies.

\section{Pollution Haven Hypothesis}

The precise relationship between environmental policy, the location of production, and subsequent trade flows remains an open and hot-button issue. Of particular concern is the so-called Pollution Haven Hypothesis (PHH), whereby differences in stringency of pollution regulation are the main factor of comparative advantage of countries. Thus, with trade, less developed countries, having weaker environmental policy, become dirtier as they will specialize in dirty-goods production. The underlying reasons for developing countries to set lower standards are threefold. Firstly, the costs of monitoring and exerting pollution standards are relatively higher in developing countries. This is caused, for example, by a scarcity of trained personnel, the high costs of implementing new pollution standards, the difficulty of obtaining modern equipment, corruption (all in comparison to developed countries).

Second, developed countries with high incomes generate a larger demand for clean water and air. Developing countries with low levels of income are more focused on extra earnings and jobs, rather than health and pollution. Third, growth in developing countries implies a shift from agriculture to manufacturing, resulting in rapid urbanization and large investments in urban infrastructure, which raises the pollution intensity. In developed countries, however, growth implies a shift from manufacturing to services, which leads to a decrease of pollution intensity.

Despite the high stakes, the existing literature has been unable to convincingly assess the empirical validity of the PHH for three reasons. First, environmental regulation is complex and multidimensional, making any empirical measure fraught with measurement error. Shadbegian and Wolverton [13] state: Measuring the level of environmental stringency in any meaningful way is quite difficult, whether at the national, state, or local level. "The difficulty arises from the fact that different regulations typically cover different pollutants, regulations may exist at multiple levels (e.g., federal and local), and monitoring and enforcement are imperfect. Along these lines, Levinson [14] states: The problem is not merely one of collecting the appropriate data; merely conceiving of data that would represent [environmental stringency] is difficult.” Xing and Kolstad [15] refer to the measurement of environmental regulation as\no easy task "due to its complexity.” Moreover, depending on the empirical measure employed, the measurement error need not be classical and any bias may be accentuated by the reliance on fixed effects methods in the recent literature.

Second, even if an accurate measure of environmental regulation is available, it may be endogenous for other reasons [16]. For example, it may be correlated with unobserved determinants of location choice such as tax breaks or other firm-specific treatments, the pro-vision of other public goods in addition to environmental quality (e.g., infrastructure), agglomeration, the stringency of other regulations such as occupational safety standards, corruption, local political activism, political institutions, etc. (see [17] for a review). In addition, reverse causation may be an issue. For instance, anticipation of low FDI in flows may drive reductions in environmental stringency.

Or, an increase in FDI may increase the efficacy of industrial lobby groups [18] [19]. Conversely, as Keller and Levinson [19] state: Those states that do not attract a lot of polluting manufacturing probably do not enact stringent regulations there simply is less need to worry about industrial pollution in states with less industrial activity, and those states that do attract polluting manufacturing may respond by enacting more stringent regulation. "Levinson [20] summarizes these arguments succinctly: International trade has environmental consequences, and environmental policy can have international trade consequences.” 
Third, existing studies of the PHH inadequately incorporate geographic spillovers. Recent theoretical models emphasize that the extent of MNE activity in one location depends not just on attributes of that location, but also on the attributes of other potential hosts. Moreover, the predicted direction of the cross-effects is not always in the opposite direction of the own-effects, a restriction that is implicit in discrete choice models [21]-[26]. Failure to account for geographic spillovers in empirical analyses of PHH may lead to biased inference. This may be particularly problematic in the context of empirical analyses of inbound U.S. FDI since state-level environmental regulations have been shown to be strongly related to the regulatory stringency of neighboring states [27].

\section{Empirical Modelling and Estimation Strategy}

The objective of present paper is to test the effect of inter-industrial trade openness on Iran's $\mathrm{CO}_{2}$ emissions via scale, technique, composite and comparative advantage effects. The model used in this study is Anthony \& Copeland \& Taylor (ACT) pollution model. Since the results and methodology of the model are the main issues of the present research, it seems useful to give a summary of the proposed model.

In contrast, ACT's model allow comparative advantage to be driven by capital and labor endowments instead of, or as well as, differences in environmental regulations. Furthermore, such environmental regulations are exogenously. Since the findings and methodology of ACT are central to this paper it is useful to provide a brief outline of the model.

Assume a small open economy produces two goods, $\mathrm{X}$ and $\mathrm{Y}$, with two factors, capital (K) and labor (L). Assume industry $\mathrm{X}$ is capital intensive and generates pollution, whilst industry $\mathrm{Y}$ is labor intensive and clean. Assuming the existence of trade barriers, if $p$ is the relative price of $\mathrm{X}$ then domestic prices will differ from world prices,

$$
p=\beta p^{w}
$$

where $\beta$ denotes trade frictions and $p^{w}$ is the common world relative price of X. Note that $\beta \succ 1$ if a country imports $\mathrm{X}$ and $\beta \prec 1$ if a country exports $\mathrm{X}$.

ACT decompose pollution (z) into scale, composition and technique effects

$$
\hat{z}=\hat{s}+\hat{\varphi}_{x}+\hat{e}
$$

where $\wedge$ denotes percentage change. Where $\hat{z}=\partial z / z$, and so on.

The first term is the scale effect. It measures the increase in pollution that would be generated if the economy were simply scaled up, holding constant the mix of goods produced and production techniques.

The second term is the composition effect as captured by the change in the share of the dirty good in national output. If we hold the scale of the economy and emissions intensities constant, then an economy that devotes more of its resources to producing the pollution good will pollute more.

Finally, we have the technique effect. Holding all else constant, a reduction in the emissions intensity will reduce pollution.

Understanding the interaction between these effects will play an important role in determining how trade and growth affect the environment.

A further decomposition of Equation (2) allows ACT to arrive at the private sector's demand for pollution. Pollution demand is a positive function of scale, capital abundance and the world price of dirty goods and is a negative function of a pollution tax. The degree of trade frictions also affects pollution demand but, as we shall see, the direction of this effect depends on whether a country is an importer or an exporter of dirty goods. In ACT's model pollution supply is determined by the price of polluting, as given by a pollution tax. In turn, real income is a determinant of the pollution tax, since an increase in real per capita income will increase the demand for environmental quality. Combining pollution demand and supply yields the following reduced form equation:

$$
\hat{z}=\gamma_{1} \hat{S}+\gamma_{2} \hat{\kappa}-\gamma_{3} \hat{I}-\gamma_{4} \hat{T}+\gamma_{5} \hat{p}^{w}+\gamma_{6} \hat{\beta}
$$

where all $\gamma_{i}$ are positive, $\boldsymbol{\kappa}$ denotes the capital-labor ratio, I represents real per capita income, $\mathrm{T}$ represents "country type" and all other variables are as already defined. We can now clearly illustrate how the direction of the trade-induced composition effect will vary across countries.

For an exporter of the dirty good, $\beta \prec 1$. As trade is liberalized $\beta$ will increase and hence $\hat{\beta} \succ 0$. Thus, for a country with a comparative advantage in pollution-intensive output, trade liberalization will increase emis- 
sions. In contrast, for a dirty good importer $\beta \succ 1$ and hence trade liberalization will mean $\hat{\beta} \prec 0$ : Thus, for a country with a comparative advantage in clean output, trade liberalization will reduce pollution.

ACT therefore derives an important result that is central in this paper. Holding other determinants of emissions constant, trade liberalization does not have a unique relationship with emissions. Rather, the effect of liberalization on the environment will be country specific and depends crucially on a country's comparative advantage.

Based on our theoretical considerations, we estimate the following equation using fixed and/or random effects of panel data specifications. Panel data analyses offer different ways to deal with the possibility of country-specific variables. Fixed Effect (FE) model is a suitable estimation approach that treats the level effects as constants, whereas Random Effect (RE) model is suitable to capture the level effect. It should be mentioned that $\mathrm{RE}$ model treats the level effects as uncorrelated with other variables, while FE model does not. In this analysis we estimate both FE and RE models. Now the estimating equation is:

$$
\begin{aligned}
E_{i t} & =\alpha_{1}+\alpha_{2} V_{i t}+\alpha_{3}\left(V_{i t}\right)^{2}+\alpha_{4} K L_{i t}+\alpha_{5} K L_{i t}^{2}+\alpha_{6} I_{i t-1}+\alpha_{7} I_{i t-1}^{2}+\alpha_{8} O P_{i t}+\alpha_{9} O P_{i t} R K L_{i t} \\
& +\alpha_{10} O P_{i t}\left(R K L_{i t}\right)^{2}+\alpha_{11} O P_{i t} R I_{i t}+\alpha_{12} O P_{i t}\left(R I_{i t}\right)^{2}+\alpha_{13} O P_{i t}\left(R K L_{i t} R I_{i t}\right)+\mu_{t}+\varphi_{i}+\varepsilon_{i t}
\end{aligned}
$$

While the fixed effects model treats the $\mu_{t}$ and $\varphi_{i}$ as regression parameters, the random effects model treats them as components of the random disturbance.

Where $\mathrm{t}$ is the year; $i$ denotes industry;

$E_{i t}$ is per capita $\mathrm{CO}_{2}$ emission.

$V_{i t}$ : value added of industry is the scale effect. We use value added as proxy for scale effect. It measures the increase in pollution that would be generated if the economy were simply scaled up, holding constant the mix of goods produced and production techniques. Trade and growth both increase real income, and therefore both increase the economy's scale.

$K L_{i t},\left(K L_{i t}\right)^{2}$ : A nation's capital to labor ratio captured to the composition effect. In our estimations we will include both a country's capital to labor ratio and its square. This non-linearity is appealing because theory suggests capital accumulation should have a diminishing effect at the margin.

$I_{t-1}, I_{t-1}^{2}$ : One lagged income per capita is the technique effect. Because we believe the transmission of income gains into policy is slow and reflects one period lagged, we use one period lagged income as our proxy for our technique effect. We have also allowed the technique effect to have a diminishing impact at the margin by entering both the level and the square of lagged income in our regression.

This use of lagged income and its squared to capture technique effects is consistent with the environmental Kuznets curve literature. This literature is the inverted-U-shaped relationship between per capita income and pollution: increased incomes are associated with an increase in pollution in poor countries, but a decline in pollution in rich countries.

$O P_{i t}$ : We include trade intensity (the ratio of imports + exports to GDP) as a measure of trade frictions.

$O P_{i t} K L_{i t}, O P_{i t}\left(K L_{i t}\right)^{2}$ : trade intensity is interacted with a country's relative capital-labor ratio and its square to capture the role of endowments.

$O P_{i t} I_{i t}, O P_{i t}\left(I_{i t}\right)^{2}$ : Trade intensity is interacted with income per capita and its square.

$O P_{i t} I_{i t}$ captures the Pollution Haven hypothesis. The differences in environmental policy among countries are a source of comparative advantage. When trade is liberalized, the developed countries with the strict environmental regulations replace the most polluting-intensive industries to the development countries with the laxer environmental regulations, therefore, the production of these industries increase in the development countries. The other part, the development countries for the world market access export the industries to other countries, thus the transport increase in the world. Therefore, the pollution haven effect causes the more pollution in the world. $O P_{i t}\left(K L_{i t} I_{i t}\right)$ represents interaction of trade openness, capital to labor ratio and national income.

ACT model shows scale effect by using $V_{i t}$ variable, since any industry activity scale is measured by industry value added. Moreover, as technology transfer is slow and its effect is reflected in long-term, income is considered as technique effect in estimation with one period delay. Square of per capita income is inserted into the model final form to show decreasing effect [3]. Using value added and income as well as their squares is to acquire scale and technique effects in line with environmental Kuznets curve theory.

With increase in trade openness, relative advantage due to industry trade is a function of two factors of relative income and frequency of capital and labor [3]. Therefore, index of commercial intensity rate as well as in- 
teraction of commercial intensity with determinants of relative advantage are used.

\section{Statistical Data and Time Series}

Data of Iran's various industrial sections extracted from Iran Statistics Center and World Bank sites (www.worldbank.org) are used in this study. Different sections of industry considered are as follows: food and beverage industry, wood and wood products manufacture, tobacco production, paper products manufacture, clothing, publishing, tannery and manufacturing of bags and shoes, oil and nuclear productions, chemical productions, production of mineral and nonmetal products, manufacturing of basic metals, producing fabric metal products except machinery and equipment, rubber and plastic products, office and accounting machinery, nonclassified equipment and machinery in other places, manufacturing non-classified electrical machineries in other places, mass media, medical, optical products, as well as time production tools, motor vehicles and trailer, manufacturing transportation equipment, and non-classified artifacts over 1980-2014.

\section{Estimation Results}

Panel regression is an efficient technique when there is a large number of cross sectional units with diverse qualitative variations. In such situation, an unrestricted intercept term is more plausible. The fixed effects (FE) estimator allows $\alpha_{i t}$ to vary across cross-section units so that we get different constants for different countries. In other words, $\theta_{i t}=\theta_{t}$ and $E\left(\theta_{i} \varepsilon_{i}\right) \neq 0$. Fixed effects regression is the model to use when you want to control for omitted variables that differ between cases but are constant over time. It lets you use the changes in the variables over time to estimate the effects of the independent variables on your dependent variable, and is the main technique used for analysis of panel data. While, if you have reason to believe that some omitted variables may be constant over time but vary between cases, and others may be fixed between cases but vary over time, then you can include both types by using random effects (RE).

We employ a Hausman test to test for the inconsistency of the random effects estimate. Furthermore, since heteroscedasticity may be present in the sample because of large variations in the variables, it needs to be tested for in the estimations. A likelihood-ratio test is used that compares a feasible general least squares regression (FGLS henceforth) that is corrected for heteroscedasticity with one that is not. Where the null hypothesis of homoscedasticity could be rejected, robust standard errors are used. A final methodological issue concerns serial correlation in the error term.

We estimate the Equation (4) using fixed and/or random effects of panel data and stata 13 for the $\mathrm{CO}_{2}$ pollution created by the different industries. The random effects model examines how group and/or time affect error variances. Lagrange-multiplier test for random effects developed by Breusch and Pagan and as modified by Baltagi et al. [25]. The Breusch-Pagan Lagrange Multiplier test for heteroskedascity is supposedly able to detect heteroskedasticity which is an arbitrary function of some set of regressors. The null hypothesis of the one-way random group effect model is that variances of groups are zero. If the null hypothesis is not rejected, the pooled regression model is appropriate.

The fixed-effects regression model estimated invokes the ordinary least squares (OLS) estimator for point and interval estimates under the classical assumptions that the error process is independently and identically distributed. The error process may be homoskedastic within cross-sectional units, but its variance may differ across units: a condition known as group wise heteroskedasticity. I need to calculate a modified Wald statistic for group wise heteroskedasticity in the residuals of a fixed-effect regression model.

Greene's discussion of Lagrange multiplier, likelihood ratio, and standard Wald test statistics points out that these statistics are sensitive to the assumption of normality of the errors. The modified Wald statistic computed here is viable when the assumption of normality is violated, at least in asymptotic terms.

I compare a fixed effect model and its counterpart random effect model by Hausman test. The Hausman specification test examines if the individual effects are uncorrelated with the other regressors in the model. Since computation is complicated, let us conduct the test in Stata.

Levin Lin \& Chu and ImPesaran and Shin W-stat tests show unit-root process. The null hypothesis is that the variable contains a unit root, and the alternative is that the variable was generated by a stationary process. We may optionally exclude the constant, include a trend term, and include lagged values of the difference of the variable in the regression.

Before we proceed with panel regression we test for the stationarity status of all variables. Therefore, we 
make the unit root test of Im, Pesaran \& Shin W-stat to test for it. The results show that all variables are stationarity at level (Table $1 \&$ Table 2).

As observed, one unit of increase in value added may lead to 5.88 decreasing of environmental quality. This result demonstrates that economic activities are along with producing dirty products and pollutants. Given that different industries value added was considered as scale effect, it can be concluded that increase in scale of industries economic activities has led to higher damaging of environment. Many studies including Grossman and krueger [1] have revealed that scale effect tends to cause environmental degradation, which is consistent with the results of present research.

As seen, the ratio of capital to labor has a positive coefficient. That means comparative advantage of different industries were toward dirty production and for one unit increase in it lead to pollution increase up to 4 units. Composition effect level depends on comparative advantage. Considering comparative advantage in a country, if any country has comparative advantage in pollutants production, it expert these products, then composition effect decreases environment quality through changing composition of domestic production towards pollutant products. If any country becomes professional in producing clean products through comparative advantage, then composition effect increases environment quality. Thus, this result indicates that different industrial sections of our country are experienced in dirty production and follow reduced environmental quality.

Positive coefficient $I_{t-1}$ shows that technology advancement is also towards producing pollutant production. One percent increase in technology led to increase 1.77 percent of $\mathrm{CO}_{2}$ pollution. This means that the technology is used for clean production.

However, in general, following trade liberalization, if technical effect outperforms scale and composition effect in a country with comparative advantage in pollutant industries and or if technical effect with composition effect in a country with comparative advantage in clean industries overcomes scale effect, trade liberalization may lead to improve environmental quality.

We calculate the total sum of three effects elasticities, if it is positive, that means trade liberalization increases environmental pollution, and in the case of negative total sum, trade liberalization leads to improved environment quality. As seen, total elasticity computed has a positive coefficient; therefore, trade liberalization leads to reduced environmental quality in different industrial sections (Table 3).

Moreover, positive coefficient of trade openness shows the effect of trade liberalization on pollution emission. Results show that one percent increase in trade openness leads to 0.0017 percent increase in environmental quality. This result indicates that increased commercial relations decrease Iran's environmental quality.

Positive coefficient of interaction between trade openness and capital to labor ratio presents that trade liberalization increase $\mathrm{CO}_{2}$ emissions. This is because Iran has comparative advantage in manufacturing products with high pollution.

Table 1. Variables stationarity test.

\begin{tabular}{|c|c|c|}
\hline \multicolumn{2}{|c|}{ Im, Pesaran \& Shin Test } & \multirow[t]{2}{*}{ Variables } \\
\hline Statistics & Prob & \\
\hline-4.869 & 0.0013 & $V_{i t}$ \\
\hline 3.179 & 0.0003 & $\left(V_{i t}\right)^{2}$ \\
\hline-8.938 & 0.0000 & $K L_{i t}$ \\
\hline-7.2222 & 0.0000 & $K L_{i t}^{2}$ \\
\hline 6.254 & 0.0000 & $I_{i t}$ \\
\hline 1.590 & 0.0000 & $I_{i t}^{2}$ \\
\hline 2.882 & 0.0053 & $O P_{i t}$ \\
\hline-6.228 & 0.0000 & $O P_{i t} K L_{i t}$ \\
\hline-2.001 & 0.0009 & $O P_{i t}\left(K L_{i t}\right)^{2}$ \\
\hline-5.007 & 0.0000 & $O P_{i t} I_{i t}$ \\
\hline-3.027 & 0.0022 & $O P_{i t}\left(I_{i t}\right)^{2}$ \\
\hline-5.027 & 0.0041 & $O P_{i t}\left(K L_{i t} I_{i t}\right)$ \\
\hline
\end{tabular}


Table 2. The determinants of $\mathrm{Co}_{2}$ emissions.

\begin{tabular}{|c|c|c|c|c|}
\hline \multicolumn{2}{|c|}{ Fixed effects model (1) } & \multicolumn{2}{|c|}{ Random effects model } & \multirow{2}{*}{ Variables } \\
\hline t & Coefficients & $\mathbf{z}$ & Coefficients & \\
\hline 5.73 & 3.03 & $5.88 *$ & 3.25 & $V$ \\
\hline-0.01 & 0.924 & -0.03 & 0.974 & $V^{2}$ \\
\hline 4.108301 & 2.88 & $4.015671^{*}$ & 2.94 & $K / L$ \\
\hline 0.6468213 & 1.08 & 0.6227391 & 1.09 & $(K / L)^{2}$ \\
\hline 1.70 & 3.40 & $1.77 *$ & 3.67 & $I_{t-1}$ \\
\hline-1.65 & -2.84 & $-1.68^{*}$ & -3.00 & $\left(I_{t-1}\right)^{2}$ \\
\hline-0.001628 & -5.47 & $-0.0017776^{*}$ & -6.19 & $O P$ \\
\hline 0.0122987 & 2.95 & $0.0117198^{*}$ & 2.94 & $O P K / L$ \\
\hline 8.19 & 2.90 & $9.04 *$ & 3.33 & $O P I_{t-1}$ \\
\hline-9.18 & -2.28 & $-9.99 *$ & -2.60 & $O P\left(I_{t-1}\right)^{2}$ \\
\hline 0.000239 & $0.35-$ & 0.000261 & -0.40 & $O P_{i t}\left(K L_{i t}\right)^{2}$ \\
\hline-1.05 & -2.76 & $-9.96 *$ & -2.75 & $O P I_{t-1}(K / L)$ \\
\hline 0.6150 & & 0.5160 & & $R^{2}$ \\
\hline 22 & & 22 & & Groups \\
\hline 770 & & 770 & & Number of observation \\
\hline 35 & & 35 & & Time periods \\
\hline $\begin{array}{l}2387.24 \\
0.0000\end{array}$ & & & & $\begin{array}{l}\text { LM Test } \\
\text { Probe }>\text { chi2 }\end{array}$ \\
\hline $\begin{array}{l}140.63 \\
0.0000\end{array}$ & & & & $\begin{array}{l}\text { Modified Wald Test } \\
\text { Probe }>\text { chi2 }\end{array}$ \\
\hline $\begin{array}{l}5.59 \\
0.2321\end{array}$ & & & & $\begin{array}{l}\text { Human Test } \\
\text { Probe }>\text { chi2 }\end{array}$ \\
\hline $\begin{array}{l}22.783 \\
0.0003\end{array}$ & & & & $\begin{array}{l}\text { Wooldridge Test } \\
\text { Probe }>\text { chi2 } 2\end{array}$ \\
\hline
\end{tabular}

Note: T-statistics are shown in parentheses. Significance at the 95\% confidence levels are indicated by*. The robust standard errors are White's heteroskedasticity-corrected standard errors. (1) The acceptation of model by the Hausman test. (2) The hausman test tests the null hypothesis that the coefficients estimated by the efficient random effects estimator are the same as the ones estimated by the consistent fixed effects estimator. If they are (insignificant P-value, Prob > chi2 larger than 0.05) then it is safe to use random effects. If you get a significant P-value, however, you should use fixed effects.

Table 3. Calculation of elasticities.

\begin{tabular}{ll}
\hline Scale Effect Elasticity & 0.409 \\
Technique Effect Elasticity & 0.076 \\
Composition Effect Elasticity & -0.194 \\
Total Effect & 0.291 \\
\hline
\end{tabular}

Positive coefficient of interaction between trade openness and income means trade liberalization with lax environmental policy reduce environmental quality. In other word, lax environmental policy increase trade and attraction of foreign investments for higher production and export of dirty products. This result shows the validity of PHH.

The coefficient of interaction between trade liberalization, capital to labor ration and income is also negative, which is due to lax environmental policy as well as technology transfer of dirty products by trade. This result also emphasizes the two earlier results.

\section{Conclusions}

This study identified the effect of inter-industrial commerce on Iran's air pollution over 1980-2014. The results 
show that trade liberalization leads to the reduction of environmental quality. This means that many economic activities of different industrial sections destroy environment at raw material extraction step, utilizing renewable resources, or waste and pollution creation. This shows that Iran has comparative advantage in producing dirty industries. Furthermore, PHH is accepted in Iran industries, because lax environmental policy increases trade and attraction of foreign investments for more production and exportation of dirty industry.

In general, obtained results reveal the necessity of some measures to be taken by which different industrial sections are related to pollutant emissions. Therefore, it is required to get environmental certificates. However, due to high costs of such standards incur, it is necessary for government to adopt supportive policy or increase the firms' incentives for this purpose.

Moreover, trade increases per capita income, then people demand cleaner and greener products. This increased trade may change economic composition to the benefit of environment. In addition, in the case of lacking such facilities, producing these types of products should technologically be improved regarding environmental quality.

\section{References}

[1] Grossman, G.M. and Krueger, A.B. (1991) Environmental Impacts of a North American Free Trade Agreement. National Bureau of Economic Research, No. w3914

[2] Copeland, B.R. and Taylor, M.S. (1994) North-South Trade and the Environment. The Quarterly Journal of Economics, 109, 755-787. http://dx.doi.org/10.2307/2118421

[3] Copeland, B.R. and Taylor, M.S. (2004) Trade, Growth and the Environment. National Bureau of Economic Research, No. 9823.

[4] Grossman G.M. and Krueger, A.B. (1993) Environment Impacts of a North American Free Trade Agreement. In: Garber, P.M. Ed., The Mexican-US Free Trade Agreement, MIT Press, Cambridge, 1-10.

[5] Baek, J., Cho, Y. and Koo, W.W. (2009) The Environmental Consequences of Globalization: A Country-Specific Time-Series Analysis. Ecological Economics, No. 68, 2255-2264. http://dx.doi.org/10.1016/j.ecolecon.2009.02.021

[6] Manni, U.H. and IbneAfzal, M.N. (2012) Effect of Trade Liberalization on Economic Growth of Developing Countries: A Case of Bangladesh Economy. Journal of Business, Economics and Finance, Universiti Brunei Darussalam, Bandar Seri Begawan.

[7] Herath, H.M.S.P. (2010) Impact of Trade Liberalization on Economic Growth of Sri Lanka: An Econometric Investigation. Wayamba University of Sri Lanka. Sri Lanka. http://www.kln.ac.lk/uokr/ICBI2010/6.pdf

[8] Panayotou, T. (1993) Empirical Tests and Policy Analysis of Development. ILO Technology and Employment Programme Working Paper, WP238.

[9] Banadkuhi, H (1999) Pollution Haven Hypothesis about Foreign Trade OECD Countries. Thesis, University of Tehran, Tehran.

[10] McConnell, K.E. (1997) Income and the Demand for Environmental Quality. Environment and Development Economics, 2, 383-399.

[11] Kriström, B. and Riera, P. (1996) Is the Income Elasticity of Environmental Improvements Less Than One? Environmental and Resource Economics, 7, 45-55.

[12] McArthur, J.W. and Sachs, J.D. (2001) Institutions and Geography: Comment on Acemoglu, Johnson and Robinson (2000). National Bureau of Economic Research, No. w8114.

[13] Baylis, J. and Smith, S. (2005) The Globalization of World Politics. Oxford University Press, New York.

[14] Chong, H.L., Khalid, A., Rusnah binti, M. and Muhammad, S. (2015) Decomposing the Trade-Environment Nexus for Malasia: What Do the Technique, Scale, Composition and Comparative Advantage Effect Indicate?

[15] Shadbegian, R. and Wolverton, A. (2010) Location Decisions of U.S. Polluting Plants: Theory, Empirical Evidence, and Consequences. International Review of Environmental and Resource Economics, 4, 1-49. http://dx.doi.org/10.1561/101.00000029

[16] Levinson, A. (2008) Pollution Haven Hypothesis. In: Durlauf, S.N. and Blume, L.E., Eds., New Palgrave Dictionary of Economics, 2nd Edition, Palgrave Macmillan, London. http://dx.doi.org/10.1057/9780230226203.1302

[17] Xing, Y. and Kolstad, C.D. (2002) Do Lax Environmental Regulations Attract Foreign Investment? Environmental and Resource Economics, 21, 1-22. http://dx.doi.org/10.1023/A:1014537013353

[18] Arauzo-Carod, J.-M., Liviano-Solis, D. and Manjón-Antolín, M. (2010) Empirical Studies in Industrial Location: An Assessment of Their Methods and Results. Journal of Regional Science, 50, 685-711. 
http://dx.doi.org/10.1111/j.1467-9787.2009.00625.x

[19] Cole, M.A., Elliott, R.J.R. and Fredriksson, P.G. (2006) Endogenous Pollution Havens: Does FDI Influence Environmental Regulations? The Scandinavian Journal of Economics, 108, 157-178. http://dx.doi.org/10.1111/j.1467-9442.2006.00439.x

[20] Cole, M.A. and Fredriksson, P.G. (2009) Institutionalized Pollution Havens. Ecological Economics, 68, $1239-1256$. http://dx.doi.org/10.1016/j.ecolecon.2008.08.011

[21] Keller, W. and Levinson, A. (2002) Pollution Abatement Costs and Foreign Direct Investment Inflows to US States. The Review of Economics and Statistics, 84, 691-703. http://dx.doi.org/10.1162/003465302760556503

[22] Levinson, A. (2010) Offshoring Pollution: Is the United States Increasingly Importing Polluting Goods? Review of Environmental Economics and Policy, 4, 62-83.

[23] Yeaple, S.R. (2003) The Complex Integration Strategies of Multinationals and Cross Country Dependencies in the Structure of Foreign Direct Investment. Journal of International Economics, 60, 293-314. http://dx.doi.org/10.1016/S0022-1996(02)00051-X

[24] Ekholm, K., Forslid, R. and Markusen, J.R. (2003) Export-Platform Foreign Direct Investment. NBER WP, No. 9517.

[25] Baltagi, B.H., Egger, P. and Pfaffermayrd, M. (2007) Estimating Model of Complex FDI: Are There Third-Country Effects? Journal of Econometrics, 140, 260-281. http://dx.doi.org/10.1016/j.jeconom.2006.09.009

[26] Baltagi, B.H., Egger, P. and Pfaffermayrd, M. (2008) Estimating Regional Trade Agreement Effects on FDI in an Interdependent World. Journal of Econometrics, 145, 194-208. http://dx.doi.org/10.1016/j.jeconom.2008.05.017

[27] Blonigen, B.A., Davies, R.B., Waddell, G.R. and Naughton, H.T. (2007) FDI in Space: Spatial Autoregressive Relationships in Foreign Direct Investment. European Economic Review, 51, 1303-1325. http://dx.doi.org/10.1016/j.euroecorev.2006.08.006 